KOREA

This is the version of the article accepted for publication in Modern Asian Studies published by Cambridge University Press: https://www.cambridge.org/core/journals/modern-asian-studies Accepted version downloaded from SOAS Research Online: http://eprints.soas.ac.uk/29904

\title{
The advance of marketization in North Korea: between political rigidity and economic flexibility
}

\section{TAT YAN KONG}

\section{Department of Politics \& International Studies}

SOAS, University of London

Email: yk2@soas.ac.uk

\begin{abstract}
North Korea is a unique regime that has not followed the 'mono transition' path (economic reform under modified one-party rule) of other surviving communist regimes (China, Vietnam, Cuba) in the post-Cold War era. Debates over North Korea's unique features (reluctance in economic reform, absence of political modification, international troublemaking) have generated two contending interpretations. The mainstream interpretation attributes North Korea's uniqueness to its regime's highly rigid political system ('monolithic leadership system'). For the alternative interpretation, structural pressures and political calculus have driven the monolithic regime towards economic reform ('marketization from above'), making it more convergent with the 'mono transition' regimes, at least in the economic aspect. In support of the latter interpretation, this article will delve further into three contentious issues that represent the most common doubts about the advance of marketization in North Korea. First, how can the regime reconcile marketization with the interests of its 'core constituencies'? Second, since 'crony socialism' exists, how does it influence distribution
\end{abstract}


KOREA

and productive activity? Third, how does marketization advance in view of the persistence of monolithic rule? In so doing, it will show how the sources of economic reform (structural factors and political calculus) have enabled the marketization constraints to be overcome.

\section{North Korea's divergence from the 'mono transition' pathway}

North Korea represents an important and puzzling case of a surviving communist regime that has not followed the 'mono transition' pathway that has enabled the China, Vietnam and Cuba to survive in the post-Cold War world. In contrast to 'dual transition' (democratization and economic liberalization), 'mono transition' is characterized gradual economic liberalization under continuing one-party rule. ${ }^{1}$ While the pace of economic transition has varied, the followers of mono transition, have exhibited a common sequence that began with official acquiescence with spontaneous marketization or 'marketization from below', followed by 'marketization from above' in which the authorities introduced gradual supporting reforms (China 1980s, Vietnam 1980s-90s, Cuba 1990s-2000s). These regimes began with encouragement of for-profit activities (by both state and non-state agents, including foreign capital), measures initially designed to complement the planned

\footnotetext{
${ }^{1}$ Kim defines it as 'implementation of gradual economic reform ${ }^{1}$ leaving the political system intact'. See I.-G. Kim, 'North Korea in transition: phased progress in reform and prospects', East $\begin{array}{llllllll}\text { Asian } & \text { Review, } & 19 & \text { (1) } & \text { (2007), } & \text { pp. 99-127, } & \text { at } & \text { p. }\end{array}$ http://www.koreafocus.or.kr/DEV/essays/view.asp?volume_id=48\&content_id=101211\&category= G [accessed 4 January 2008]
} 
KOREA

economy than replace it altogether. ${ }^{2}$ The advance of marketization to a critical level was then accompanied by the revision of the official economic ideology. Marking the primacy of the market, China replaced 'socialism with Chinese characteristics' (1980s) with the new slogan of 'socialist market economy' in $1992 .^{\mathbf{3}}$ The more orthodox-inclined Cuban regime adopted the slogan of 'prosperous-and sustainable socialism' in 2012 to acknowledge the permanence of the market. ${ }^{4}$

China's stellar economic performance compared to Russia's sluggishness touched off debates about the utility of authoritarianism to market transition and the nature of regime durability. For Brus, a noted East European political economist, China showed how authoritarianism enabled the market reforms to be introduced incrementally while Gorbachev's deliberate weakening of the Soviet regime snowballed into the overthrow of communist rule itself. ${ }^{5}$ For Wintrobe, a formal theorist of authoritarianism, the repressive nature of China's regime enabled it to perform the 'totalitarian twist' by overcoming the three main market reform problems (enterprise accountability, dual pricing and inflation). ${ }^{6}$ Pursuing very

\footnotetext{
${ }^{2}$ A.Y. So and Y.-W. Chu, The Global Rise of China, Polity Press, Cambridge 2016, pp. 63-71; R.I. Centeno, 'The Cuban regime after a decade of Rául Castro in power', Mexican Law Review, 9 (2) (2017), pp. 99-126.

${ }^{3} \mathrm{~J} . \mathrm{Wu}$, 'China's transition to a market economy: how far across the river?' in Transition from Socialist to Market Economies: Comparison of European and Asian Experiences, S. Ichimura, T. Sato, and W. James (eds), Palgrave-Macmillan, Basingstoke, 2009, pp. 37-66, at p. 41.

${ }^{4}$ Centeno, op. cit., p. 115.

${ }^{5}$ W. Brus, 'Marketization and democratization: the Sino-Soviet divergence', Cambridge Journal of Economics, 17 (4) (1993), pp. 433-444.

${ }^{6}$ R. Wintrobe, The Political Economy of Dictatorship, Cambridge University Press, New York, 1998.
} 
KOREA

similar economic reforms, the pluralized Soviet regime was left completely paralysed. Detailed case studies of communist regimes on the 'mono transition' path (notably China and Vietnam) have shown how that strategy could reinforce oneparty rule by enabling the regime to capture new market spaces. ${ }^{7}$ Within the limits of one-party rule, these regimes have also gradually modified their political institutions (e.g. from monolithic to collective leadership, greater intra-party democracy, even local level elections with non-party candidates) to make them more compatible with the social changes brought about by marketization. These modifications facilitated the evolution of the regimes of China and Vietnam from 'early post-totalitarianism' of the 1980 s to the 'maturing post-totalitarianism' of the 2000s. ${ }^{8}$

North Korea's divergence from the 'mono transition' pathway is apparent from its slower economic growth during the post-Cold War era. Though not fully reliable for socialist economies, data of estimated GDP growth (Table 1) provide at least a rough indicator of the extent to which North Korea has lagged behind not only China and Vietnam, but also Cuba (considered the most reluctant reformer of the three).

Table 1 about here

\footnotetext{
${ }^{7}$ On Cuba, see J. Corrales, 'The gatekeeper state: limited economic reforms and regime survival in Cuba, 1989-2002', Latin American Research Review, 39 (2) (2004), pp. 35-65. On China, see S. Eaton, The Advance of the State in Contemporary China: State-Market Relations in the Reform Era, Cambridge University Press, Cambridge, 2015.

${ }^{8}$ S. Saxonberg, Transitions and Non-Transitions from Communism: Regime Survival in China,
} Cuba, North Korea and Vietnam, Cambridge University Press, Cambridge, 2013, pp. 58-66 and 88103. 
The pattern of growth appears to mirror the inconsistent economic reform pattern. Just three years after their official launch in 2002, reforms began to stall from 2005. Anti-marketization policies (2005-9) initiated a period of stagnation. The growth rate has remained sluggish during 2010-15 despite the return to market toleration from 2010 and succession by an ostensibly pro-reform leader in 2012. This suggests that reform efforts have been inadequate. Apart from the inconsistent reform pattern, North Korea is distinguished by its isolation from foreign direct investment (FDI), a staple ingredient of 'mono transition', owing to its proliferation of Weapons of Mass Destruction (WMD). ${ }^{9}$.

\section{Mainstream interpretation: political rigidity as the source of divergence}

Many leading authors attribute North Korea's poor economic performance and the inconsistent economic reform pattern to the effects of its Monolithic Leadership System (MLS). Unlike the 'mono transition' regimes, North Korea has not experienced significant modification of the original Stalinist or 'totalitarian' ${ }^{10}$ form of governance (i.e. concentration of political and economic power in the vanguard

\footnotetext{
${ }^{9}$ Here understood to mean nuclear weapons and sophisticated means for their delivery.

${ }^{10}$ The Stalinist type of regime (together with German fascism) belongs to the totalitarian regime type characterized by the existence of a monistic centre of power, exclusive ideology defined by the rulers, and mass mobilization for political and social tasks. See J.J. Linz, Totalitarian and Authoritarian Regimes, Lynne Rienner, Boulder, 2000, p. 70.
} 
KOREA

party under top-down leadership). ${ }^{11}$ Threatened by the post-Stalinist trend sweeping the Soviet Bloc after 1956, the Kim Il-Sŏng regime pursued an intensified form of Stalinism that culminated in the establishment of the MLS. Compared with classic Stalinism, the MLS elevated the status of Supreme Leader or suryong, to the extent of creating a high degree of personal power unmatched in the communist world. ${ }^{12}$ Replacing the Marxism-Leninist formulation of the primacy of the vanguard party, 'Kimilsŏngism' stressed the decisive importance of the Supreme Leader in advancing the cause of the revolution. ${ }^{13}$ Since the fate of the party, state, and even nation all depended on the Supreme Leader, ${ }^{14}$ obedience to and protection of the Supreme Leader became the highest duty for all party-state agencies and for each and every citizen. Identification with national salvation further elevated the status of the Supreme Leader. It bound national sovereignty $\left(\text { chuch }^{\prime}\right)^{15}$ tightly to the Stalinist form of governance. The prevalence of such 'national Stalinism' forestalled the emergence of the more innovative forms of 'national communism' practised by the

\footnotetext{
${ }^{11}$ Brus characterized the system as 'the amalgamation of strictly political with economic power'. See W. Brus, 'Political pluralism and markets in communist systems' in Pluralism in the Soviet Union: Essays in Honour of H. Gordon Skilling, S.G. Solomon (ed.), Palgrave Macmillan, Basingstoke,1983, pp. 108-30.

${ }^{12}$ Wonjun Song and Joseph Wright, 'The North Korean autocracy in comparative perspective', Journal of East Asian Studies, 18 (2) (2018), pp. 157-80, at pp. 164-5.

${ }^{13}$ S.-C. Cheong, 'Stalinism and KimIlsungism: a comparative analysis of ideology and power', Asian Perspective, 24 (1) (2000), pp. 133-61 at pp. 146-51.

${ }^{14}$ K.-D. Lee, The Successor Theory of North Korea, Korea Institute of National Unification Studies Series 04-1, Seoul, 2004.

${ }^{15}$ Chuch'e (Juche) represents Kim Il-Sŏng's brand of nationalism that was defined by national sovereignty; self-reliant economy; and self-reliance in defense.
} 
KOREA

regimes of Yugoslavia, China, Vietnam and $\mathrm{Cuba},{ }^{\mathbf{1 6}}$ all of which would eventually follow the 'mono-transition' path.

With the Supreme Leader deified as an indispensable social transformer and national saviour, the MLS developed into a system of 'totalitarian patrimonial' rule that combined Stalinist instruments of governance, nationalism and personal authority. ${ }^{17}$ In contrast to classic Stalinism, the personality cult of the Supreme Leader also extended to key members of his family (wife, son and ancestors). This justified hereditary succession, a feature unique to North Korea in the communist world. Hereditary succession would supposedly generate a successor of the same revolutionary pedigree as the Supreme Leader, enabling the revolutionary project to advance 'from generation to generation' (Lee 2004: 30-4). In practice, hereditary succession was designed ensure the stable transfer of power to a similar type of successor who would preserve the Supreme Leader's legacy (and forestall the postStalin and post-Mao experiences of policy revision). The extension of the personality cult to the Supreme Leader's family enabled the regime to portray itself in a benign paternal manner (an image continuously reinforced by propaganda). This has led to characterizations of North Korea as a "corporate state' 18 and as a 'family state'. ${ }^{19}$ The familial aspect was much stronger in North Korea than in other

\footnotetext{
${ }^{16}$ C. Chen, and J.-Y. Lee, 'Making sense of North Korea: "national Stalinism” in comparativehistorical perspective', Communist and Post-Communist Studies, 40 (4) (2007), pp. 459-75.

${ }^{17}$ Saxonberg, op. cit., p. 119

${ }^{18}$ B. Cumings, 'The corporate state in North Korea', State and Society in Contemporary Korea, H. Koo (ed.), Stanford University Press, Stanford, 1993, pp. 197-230.

${ }^{19}$ B.-H. Chung and H. Kwon, North Korea: Beyond Charismatic Politics, Rowman \& Littlefield, Lanham, 2012.
} 
KOREA

communist regimes where a degree of familial influence also prevailed (notably Romania and Cuba).

These 'totalitarian patrimonial' features would seem to make North Korea uniquely resistant to economic reform. By ensuring the stable transfer of power to a similar type of successor, hereditary succession also forestalled the political succession struggles that provided the impetus to economic reform in the USSR and China. The typical side-effects of reform (rise of non-state economic agents, dilution of loyalty by materialism, weakening of information control) that have challenged the mono transition regimes (notably China during the Tiananmen Crisis of 1989) have the potential to be fatal to North Korea's 'totalitarian patrimonial' rulers. They stand to lose their personalized control over economic resources and they become vulnerable to the inflow of outside information (especially from rival South Korea) that may question the official accounts of their achievements, in effect, eroding both the material and subjective bases of their personality cults. It is not that North Korea's rulers do not understand the benefits of economic reform, rather they are too risk-averse to implement reform in a decisive manner. Trapped in a 'reform dilemma', it is political risk aversion and traditional ideology that the ultimately prevails over half-hearted reformism..$^{20}$

Some studies have attempted to show how, over two decades, the political interests of the rulers thwarted the economic reforms needed to boost national welfare. In response to the famine of 1995-7 ('arduous march'), the regime chose to safeguard food supplies for the military under the doctrine of 'military first politics' (sŏn'gun chŏngc'hi) than release them for popular consumption. The regime did not

\footnotetext{
${ }^{20}$ V.D. Cha, 'The North Korea question', Asian Survey, 56 (2) (2016), pp. 243-69, at p. 249.
} 
KOREA

draw on its financial reserves to import food but instead appealed for international aid. Those least politically prioritized were forced to fend through informal marketization, a process that was hindered by official criminalization of commercial activities and internal migration. ${ }^{21}$ Although the top-down reforms of 2002 were unprecedented by North Korean standards, they were actually motivated by the regime's political impulse to tame and control the spontaneous market mechanisms unleashed by the famine. Alongside the devolution of authority and introduction of incentives, the regime was introducing monetary and financial measures to destroy private wealth (by price appreciation). In other words, pro-market measures were simultaneously being countered by anti-market ones. ${ }^{22}$

The period of reform was also very brief. From late 2005, the regime attempted to restore the rationing system and then in 2008, it announced a restriction prohibiting participation in markets by those under the age of 40 . This culminated in attempts in 2009 to turn general markets back into farmers' markets. Later that year, the regime attempted to destroy accumulated private wealth by currency redenomination. Marketization was happening in spite of, and not because of, the regime. ${ }^{23}$ The 'reforms' of the current Kim Chŏng-Ŭn regime are said to follow a

${ }^{21}$ S. Haggard and M. Noland, Witness to Transformation: Refugee Insights into North Korea, Petersen Institute for International Economics, Washington DC, 2011, p. 86.

${ }^{22}$ Ibid. p. 121.

${ }^{23}$ S. Haggard and M. Noland, Famine in North Korea: Markets, Aid and Reform, Columbia University Press, New York, 2007, p. 215; U.-C. Yang, 'Reform without transition: the economic situation in North Korea since the July 1, 2002, measures', North Korean Review, 6 (1) (2010), pp. $71-87$. 
similar pattern of acknowledging the 'facts on the ground' that it cannot control ${ }^{24}$ while avoiding fundamental market-enhancing reforms (e.g. legal safeguarding of private property rights, official marketization of the factors of production, genuine openness to FDI). One empirical study of the post-succession personnel structure of the current Kim Chŏng-Ŭn regime suggests that the political economic pattern is continuing as before. ${ }^{25}$ Moreover, the frequent use of terror by Kim Chŏng- $\breve{n}$ would not appear to provide a stable environment for marketization.

Unable to fully restore the state allocation system, the regime acquiesces to marketization to the extent necessary for its survival. Writing about the Former Soviet Union and Eastern Europe, Hellman observed how the winners of partial marketization constituted the biggest obstacles to comprehensive reform. ${ }^{26}$. Lacking democratic institutions of any sort and with state ownership still prevalent (hence I use the term 'crony socialism'), North Korea arguably represents the most extreme example of this phenomenon. The core power agencies of the party-state monopolize the most lucrative foreign exchange activities (raw materials). To lock in their privileges, the regime and its chief stakeholders maintain the existing institutional environment. This enables them to stifle the emergence of competition from independent entrepreneurs. ${ }^{27}$ Denied access to the most lucrative opportunities, most

\footnotetext{
${ }^{24}$ M. Noland, 'The elusive nature of North Korean reform', Asia Pacific Issues: Analysis from the $\begin{array}{llll}\text { East-West } & \text { Center, } & \text { No. } & 108,\end{array}$
} http://www.eastwestcenter.org/sites/default/files/private/api108.pdf [accessed 4 February 2014]

${ }^{25}$ S. Haggard, L. Herman and J. Ryu, 'Political change in North Korea: mapping the succession', Asian Survey, 54 (4) (2014), pp. 773-800.

${ }^{26} \mathrm{~J}$. Hellman, 'Winner takes all: the politics of partial reform in post-communist transitions', World Politics, 50 (2) (1998), pp. 203-34.

${ }^{27}$ Haggard and Noland (2007), op. cit., p. 217 
KOREA

non-state economic agents feed off the economic crumbs of marketization. This 'economic logic of autocracy', means low growth, low productivity and continuing poverty for the majority. ${ }^{28}$ This is because export earnings (or 'rent income') are not reinvested into boosting productivity (e.g. investment into higher value manufacturing) but distributed according to political loyalty or consumed wastefully (e.g. construction of propaganda monuments or ski resorts). ${ }^{29}$ North Korea's external troublemaking is said to follow from domestic political and economic rigidity. To supplement its inadequate resources, the regime resorts to nuclear leverage in place of serious economic reform. ${ }^{30}$ Thus North Korean diplomats have constantly underlined their country's difference from 'mono transition' regimes like China or Vietnam. ${ }^{31}$

\section{Alternative interpretation: economic flexibility despite political rigidity}

The alternative perspective is based on economic indicators suggestive of better performance. Supplied by Seoul's Bank of Korea, standard GDP estimates have been

\footnotetext{
${ }^{28}$ H.-J. Park, 'How has North Korea avoided collapse and reform/openness?', Korea Focus, (2013a)
}

http://www.koreafocus.or.kr/DEV/essays/view.asp?volume id=139\&content_id=104762\&category $\equiv \mathrm{G}$ [accessed 15 January 2014]

${ }^{29}$ H.-J. Park, 'Expanding North Korea-China economic cooperation and the future of the North Korean regime: a "rentier state" analysis', KINU Online Series CO11-09 (2011), http://repo.kinu.or.kr/bitstream/2015.oak/1870/1/0001447701.pdf [accessed 10 October 2011]

${ }^{30}$ For example, see J.D. Pollack, No Exit: North Korea, Nuclear Weapons and International Security, International Institute for Strategic Studies, London, 2010.

${ }^{31}$ Cha, op. cit., pp. 254-6. 
KOREA

criticized for neglecting the role of the informal economy. ${ }^{32}$ The inclusion of the service-oriented informal sector would probably add one or two points to the GDP growth rate. ${ }^{33}$ The rapid growth of trade since 2010 would also suggest a much higher rate of GDP growth. Total trade (including inter-Korean trade) grew from USD 5,093 million (2009) to USD 8,966 million (2015). ${ }^{34}$ The level of trade would suggest recovery of GDP to the pre-crisis levels (at the worst point of the famine in 1997, it was USD 2,490 million). ${ }^{35}$ Analyses of North Korea's own budget data show revenue growth to have constantly exceeded expenditure growth during the Kim Chŏng-Ǔn era. ${ }^{36}$ Using official budget data as the proxy for GDP growth, Frank calculated a robust 6.1 per cent growth rate (2016) and predicted a slower but

\footnotetext{
32 The Bank of Korea's centrally planned economy model estimates the service sector occupies only 30 per cent of the entire economy, of which two-thirds belongs to the state sector, leaving one third (or 10 per cent of the economy) for private service activities. See M.-S. Yang, 'North Korea's domestic economic policy and economic management improvement measures', in 2015 DPRK Country Report, Korea Development Institute School of Public Policy \& Management and Institute for Far Eastern Studies (IFES) (eds), KDI School and IFES, Seoul, 2015c, pp. 92-126, at pp. 104-5.

${ }^{33}$ M.-S. Yang, 'The evaluation of 2015 and prospects for 2016: North Korean economy', IFES Issues and Analysis, 2015a, http://ifes.kyungnam.ac.kr/eng/FRM/FRM 0401L.aspx [accessed 5 January 2016]

${ }^{34}$ National Statistics Office (NSO), Major Statistics Indicators of North Korea, NSO, Seoul, several issues.

${ }^{35}$ H. Feron, 'Doom and gloom or economic boom? The myth of the "North Korean collapse", The Asia Pacific Journal: Japan Focus, 12:18 (3) (2014), http://apjjf.org/2014/12/18/Henri-
} Feron/4113/article.html, [accessed 3 March 2015]

36 R. Frank, 'The 2016 North Korean budget report: 12 observations', 38 North, 2016a http://38north.org/2016/04/rfrank040816/[accessed 5 September 2016] 
respectable 3.1 per cent for 2017 (probably owing to tighter Chinese sanctions) ${ }^{37}$ On the consumption front, international estimates of grain production revealed a fouryear upward trend (2010-11 to 2015-6) in domestic grain production that was approaching the pre-1990s crisis levels. ${ }^{38}$ The number of mobile phone subscribers, a telling indicator of consumerism, increased from 432,000 (2010) to 2.42 million (2013) to 3.24 million (2015) i.e. from 1.76 subscribers per 100 persons (2010) to 12.88 per $100(2015){ }^{39}$

These indicators of economic improvement have coincided with the return to acquiescence with the market in the final years of the Kim Chŏng-Il regime (201011) and the consolidation phase of the Kim Chŏng-Ŭn regime (since 2012). Measures since 2012 suggest more than acquiescence with the market. Not long after Kim Chŏng-Ŭn assumed the top post of First Secretary of the ruling Korean Workers' Party (KWP) (27 March 2012), he publicly pledged never to repeat the

\footnotetext{
${ }^{37}$ R. Frank, 'The North Korean parliamentary session and budget report for 2017', 38 North, 2017a, http://www.38north.org/2017/04/rfrank042817/ [accessed 8 May 2017]
}

${ }^{38}$ Against a minimal requirement of 5.5 million tons, the food balance (million tons) by marketing year (i.e. from November to October) was as follows: 5.04 (2010-11); 5.27 (2011-12); 5.73 (201213); 5.93 (2013-14); 5.94 (2014-15). See FAO (Food and Agriculture Organization) of the UN and World Food Programme (WFP), FAO-WFP Crop and Food Security Assessment Mission to the DPRK: Special Report (23 November 2013), http://www.fao.org/docrep/019/aq118e/aq118e.pdf [accessed 15 January 2014]; FAO, 'The DPRK: outlook for food supply and demand 2014/15 (November/October)', Global Information and Early Warning System (GIEWS) Update on Food and Agriculture, (3 February 2015), http://www.fao.org/3/a-i4363e.pdf [accessed 10 April 2016]; FAO, 'The DPRK: outlook for food supply and demand 2015/16 (November/October)', GIEWS Update on Food and Agriculture, (27 April 2016), http://www.fao.org/3/a-i5572e.pdf [accessed 9 July 2016].

${ }^{39}$ NSO, op. cit. 
KOREA

austerity of the past (15 April 2012). 'Marketization from above' was restarted in June 2012 ('June 28th Measures') and followed by further measures in May 2014 ('May 30th Measures'). These micro-economic reforms sought to utilize the profit motive and local autonomy to boost the productivity of state-owned agriculture and light industry, key sectors serving the People's Economy. ${ }^{40}$ While retaining formal state ownership, the measures opened up further opportunities for non-state agents (i.e. entrepreneurs, merchants and financiers). This 'socialist management of our own style' resembled Chinese 'dual track' reforms of the 1980s when the planned and market economies co-existed. ${ }^{41}$ Another aspect of 'marketization from above' was the opening up of new opportunities for non-state agents in key social infrastructural projects (especially housing) and consumption activities (e.g. retail and entertainment facilities).

Explanations for the return of 'marketization from above' attribute this phenomenon to the combination of structural pressure and political calculus. At the structural level, the 1990s collapse of the formal economy necessitated spontaneous marketization at the grassroots ('marketization from below') and devolution of financial responsibility to the core party-state agencies themselves. As a result, the market activities of the people and the core agencies became entwined on many levels. ${ }^{42}$ Marketization became a major source of income for the core agencies (via

\footnotetext{
${ }^{40}$ It denotes the part of the economy controlled by the Cabinet and is responsible for supplying the ordinary citizens.

${ }^{41}$ K. Gray and J.-W. Lee, 'Following in China's footsteps? The political economy of North Korean reform', The Pacific Review, 30 (1) (2017), pp. 51-73, at pp. 59-65.

${ }^{42}$ S.-H. Lim, The Rise of Markets within a Planned Economy, Samsung Economic Research Institute, Seoul, 2009; H.-M. Joo, 'Visualising the invisible hands: the shadow economy in North
} 
KOREA

export monopolies) and greatly enriched their leaders. As a result, those non-state agents with invaluable skills and contacts also prospered as economic partners. Officials at all levels gave protection to market activities in order to supplement their inadequate state salaries. According to Suk-Jin Kim, most restrictions could be 'bypassed through bribery and punishments are not very severe' ${ }^{43}$ As North Korea's principal trading partner, Chinese economic entities have been a vital force in fuelling the trend of marketization by promoting for-profit transaction. ${ }^{44}$ More fundamentally, Lee has argued that since 2013, the principal currencies of transaction have become the US dollar (and other hard currencies) and the dollarpegged North Korean won. Dollar-pegging means that regardless of whether economic activity is official (i.e. within the 'planned' sector) or informal, it is governed by a capitalist logic (of having to earn dollars or dollar-pegged won). ${ }^{45}$

Against the background of structural pressure, political calculus helps to explain the variations in the marketization trend. Here, the foremost aspect would be the second hereditary succession. In 2008, North Korea faced great uncertainty both externally (hostile conservative administration in Seoul) and domestically as Kim Chŏng-Il's health sharply deteriorated. To build a solid basis for the accelerated succession by his inexperienced youngest son Chŏng-Ŭn, Kim Chŏng-Il turned

Korea', Economy \& Society, 39 (1) (2010), pp. 110-45; H. Smith, North Korea: Markets and Military Rule, Cambridge University Press, Cambridge, 2015.

${ }^{43}$ S.-J. Kim, 'North Korea's economy under Kim Jong-Un: performance and outlook', Vantage Point: Developments in North Korea, 38 (8) (2015b), pp. 10-14, at pp. 12-13.

44 J. Reilly, 'China's market influence in North Korea', Asian Survey, 54 (5) (2014), pp. 894-917.

${ }^{45}$ S. Lee, 'Overview: growth, dollarization and the emergence of a dual economy' in 2016: The DRPK Economic Outlook, S. Lee (ed.), Korea Development Institute, Sejong City, 2017, pp. 14-37, at pp. 22-30. 
towards closer relations with China from 2009 (while ending the domestic antimarketization campaign in 2010). Switching its emphasis from aid to for-profit transactions, China pledged investment for ambitious infrastructural and production projects. Trade increased dramatically between 2010 and $2013 .{ }^{46}$ In order to consolidate its power, the new leadership of Kim Chŏng- $\breve{n}$ built upon this momentum for marketization. As a third-generation successor, Kim Chŏng-Ǔn could not rely on bloodline inheritance to the same extent as his father (who spent decades moulding his public image). ${ }^{47}$ By contrast, he had to build his legitimacy on performance in the economic sphere. In his first public speech (April 15th 2012) he pledged never to return to austerity:

It is our party's resolute determination to let our people who are the best in the world, our people who have overcome all obstacles and ordeals to uphold the party faithfully, not to tighten their belts again and enjoy the wealth and prosperity of socialism as much as they like ${ }^{48}$

\footnotetext{
${ }^{46}$ North Korean export figures to China (USD millions) were: 793 (2009); 1,188 (2010); 2,464 (2011); 2,458 (2012); 2,914 (2013): 2,841 (2014); 2,484 (2015). Import figures (USD millions) were: 1,888 (2009); 2,278 (2010); 3,165 (2011); 3,528 (2012); 3,633 (2013): 4,023 (2014); 3,226 (2015). See NSO, op. cit.

${ }^{47}$ R. Frank and P.H. Park, 'From monolithic totalitarianism to collective authoritarian leadership? Performance-based legitimacy and power transfer in North Korea', North Korean Review, 8 (2) (2012), pp. 32-49, at p. 43.

${ }^{48}$ http://www.northkoreatech.org/2012/04/18/english-transcript-of-kim-jong-uns-speech/ [accessed 15 May 2015]
} 
KOREA

Looking to preserve power over a 40 to 50 -year timeframe, the 30 -something Kim

Chŏng-Ŭn has had to think more about comprehensive economic reform. ${ }^{49} \mathrm{Kim}$ Chŏng-Il was reportedly involved in designing his son's formulation of an economybased ruling strategy. ${ }^{50}$

\section{Delving further into the sources of economic reform: three contentious} issues

The alternative explanation invites further consideration of three contentious issues that represent the most common doubts about the advance of marketization in North Korea. First, how does the regime reconcile marketization with the interests of the 'core constituencies' that depend on the unreformed economy? 'Core constituencies' consist of servicemen, ${ }^{51}$ residents of the capital P'yŏngyang, ${ }^{52}$ munitions and

\footnotetext{
49 A. Lankov, 'Kim Jong Deng: Why North Korea is choosing market reforms'. Carnegie Moscow Centre, 2015, http://carnegie.ru/commentary/59170 [accessed 12 January 2016]

${ }^{50}$ S.-C. Cheong, 'An examination of the possibility of pushing ahead with a policy for reforms and an opening-up by the Kim Jong-Un regime', Vantage Point: Developments in North Korea, 36 (2) (2013), pp. 48-57, at p. 50

51 This denotes those in active military service (men aged 17-27) (inmingun changbyŏng) who also perform vital economic tasks (such as construction, disaster relief) designated by the state.

${ }^{52}$ Using data from North Korea's 2008 (foreign-assisted) census, Suk Lee estimated a per capita income of USD 948-1,361, making North Korea one of the world's poorest countries. P'yŏngyang, however, enjoyed a per capita income of USD 2,658-2,715. See S. Lee, 'How high is North Korea's real Employment and income?', KDI Focus, No. 78, 2016, https://papers.ssrn.com/sol3/papers.cfm?abstract_id=2888769 [accessed 4 may 2017]
} 
KOREA

strategic industry labourers, and middle and senior government and party officials. ${ }^{53}$ Some scholars think that these relatively privileged sectors represent 'the people' that Kim Chŏng-Ŭn pledged to protect from austerity. ${ }^{54}$ The regime's interest in perpetuating monolithic rule would not appear to be served by shaking up the inefficient remnants of planning and rationing that benefit these loyalists. For example, the regime appears determined to revive some of the inefficient heavy industries (e.g. synthetic fibre, steel) by modifying their operation, instead of focusing on light industry as South Korea had done during the $1960 \mathrm{~s} .{ }^{55}$ To some critics, Kim Chŏng-Ǔn's 'reforms' resemble his father's reluctant acquiescence rather than genuine enthusiasm for the market. ${ }^{56}$

Some scholars have expressed doubts as to whether the current regime can free itself from the 'military-first politics' inherited from Kim Chŏng-Il. For example, the South Korean government branded Kim Chŏng-Ǔn's 'line of parallel advance' (i.e. nuclear-based defence with economic development) as the continuation of the failed military-biased policies of his grandfather and father, but given a nuclear

\footnotetext{
${ }^{53}$ M. Cho (2013), 'The economic policies in North Korea under the leadership of Kim Jong-Un', Vantage Point: Developments in North Korea, 36 (5) (2013), pp. 48-57, at p. 55.

${ }^{54}$ For example, as of December 2008, core constituents could purchase rice at 45 won per kilo against a market price of 2000 won. See Y-H. Lee, 'Changes in North Korean economic structure and prospects of reform and opening in the Kim Jong-Un era', Vantage Point: Developments in North Korea, 37 (7) (2014), pp. 47-56, at p. 51.

${ }^{55}$ S.-J. Kim, 'North Korea's economy under Kim Jong-Un: performance and outlook', Focus on Korean Peninsula 32 (2) (2015a), pp. 1-9, at p. 6.

${ }^{56}$ For example, Noland, op. cit., p. 4.
} 
KOREA

twist. ${ }^{57}$ From a formal theoretical perspective, Wintrobe described 'military first politics' as the 'militarization of society', a unique escape act that enabled the Kim Chŏng-Il regime to resort to military rule without incurring the normal trade-off between military and civilian loyalty. However, the insatiable military demand for resources will only make it more difficult for North Korea to carry out economic reforms in the footsteps of China or Vietnam. ${ }^{58}$ These factors lead some writers to predict a future of 'simple reproduction' (i.e. slow growth without qualitative change) than the continuous advance of marketization. ${ }^{59}$

Second, the evidence of growth based on trade does not fully dispel the 'crony socialism' problem alluded to above. Critics have argued that 'growth' represents a superficial improvement based on the temporary increase of raw materials exports (especially coal and iron ore) to China since 2010. These are said to be classic 'point source' assets whose revenues can be easily captured by the state and channelled into showcase projects such as ski resorts, amusement parks and WMDs. ${ }^{60}$ However, the prospect of declining Chinese demand (in response to continuous nuclear provocations) is set to reduce North Korea's foreign exchange receipts. ${ }^{61}$

${ }^{57}$ Ministry of Unification Understanding North Korea 2014, Institute for Unification Education, Seoul, 2014, p. 267.

${ }^{58}$ R. Wintrobe, 'The logic of the North Korean dictatorship', NEPS Working Paper Series 5/2-13, 2013, http://www.europeanpeacescientists.org/5 2013.pdf [accessed 12 August 2014]

${ }^{59}$ For example, see Cho, op. cit. pp. 54-5

60 For example, M. Noland, 'Why is North Korea growing', North Korea: Witness to Transformation, 2015, https://piie.com/blogs/north-korea-witness-transformation/why-north-koreagrowing [accessed 15 November 2015]

${ }^{61}$ K.-S. Lee, 'Current trends and characteristics of the North Korean economy and its future outlook at the $70^{\text {th }}$ anniversary of the founding of the WPK', in 2016 DPRK Country Report, Korea 
More fundamentally, the control of these lucrative raw material resources under the monolithic regime is based on the proximity to power rather than entrepreneurial skill. To build and maintain the system of monolithic rule, Kim Chŏng-Ǔn's predecessors had allocated the most lucrative economic assets to the core party-state agencies, namely the military, Korean Workers' Party (KWP) and security agencies. Based on political patronage rather than entrepreneurship, this pattern of profit taking does not favour long-term investment and growth. ${ }^{62}$ Given that economic benefit is derived from power, the cronies have no incentive to promote market institutions that might nurture competitive entrepreneurship. ${ }^{63}$ On the contrary, they stand to benefit from crackdowns that restrict competition. ${ }^{64}$ Under this 'economic logic of autocracy', ${ }^{65}$ the economy remains trapped in low productivity raw material exports while the wealth gap widens in favour of the cronies. ${ }^{66}$

Development Institute School of Public Management (ed.), KDI School, Seoul, 2015, pp. 117-44, at pp.121-30

${ }^{62}$ Haggard and Noland (2007), op. cit., pp. 190-1, 216-7

${ }^{63}$ For example, a 2007 survey of 250 Chinese firms operating in North Korea found that the North Korean state (via state-owned enterprises and state licensed-agents) monopolized the most profitable activities associated with Chinese trade and investment. See S. Haggard and M. Noland, 'Networks, trust and trade: the micro-economics of China-North Korea relations', Peterson Institute for International Economics Working Paper WP12-8, 2012, https://piie.com/publications/workingpapers/networks-trust-and-trade-microeconomics-china-north-korea-integration [accessed 15 March 2013]

${ }^{64}$ M.-S. Yang, North Korea's Planned Economy and Marketization, Institute for Unification Education, Seoul, 2015e, pp. 84-5.

${ }^{65}$ H.-J. Park (2013a) op. cit.

${ }^{66}$ Chang cites a survey of 500 defectors revealed that the highest to lowest income quintile distribution to be 45 times based on their private economic activities. The corresponding ratio for 
KOREA

As the dispenser of patronage, the Supreme Leader reinforces his own power and resources by encouraging competition among the core agencies. ${ }^{67}$ The highly publicized purge of Kim Chŏng-Ǔn own uncle's Chang Sŏng-T’aek (reputed number two of the regime) in 2013, illustrates the workings and excesses of this method of rule. Kim Chŏng-Ǔn's father had allowed Chang and his Administration Department of the KWP to acquire an 'economic small kingdom' in order to counterbalance the privileged military and the Organization and Guidance Department of the KWP. ${ }^{68}$ While the immediate cause of Chang's downfall was his lieutenants' defiance of Kim Chŏng-Ŭn direct order (to surrender a fish farm), the economic background to the collective upsurge against him was his domination of the lucrative export of coal, cutting out other influential agencies and the even Supreme Leader. ${ }^{69}$ After the purge, some of Chang's assets were reportedly re-acquired by the military

South Korea (2014) was 5.4 times. See Y.-S. Chang, 'The evaluation of 2015 and prospects for 2016 : North Korea's domestic politics', IFES Issues and Analysis No. 35 (2015-12), 2015, http://ifes.kyungnam.ac.kr/eng/FRM/FRM_0401V.aspx?code=FRM151215 0001 [accessed 18 January 2016]

${ }^{67}$ Y.-J. Park, 'Informal political system in North Korea: systematic corruption of "power-wealth symbiosis"', International Journal of Korean Unification Studies, 24 (1) (2016b), pp. 123-56, at p. $147-8$.

${ }^{68}$ H.-J. Park, 'The ups and downs of the military's influence in the period of Kim Jong-Un's power consolidation (2009-2013), KINU Online Series CO13-23, 2013b, https://www.facebook.com/KINU1991eng/ [accessed 22 December 2013]

${ }^{69}$ K.E. Gause, 'North Korean political dynamics of the Kim Jong-un era', International Journal of Korean Unification Studies, 25 (1) (2016), pp. 33-63, at p. 51. 
while others went to Kim Chŏng-Ǔn's own economic office. ${ }^{70}$ This episode suggests that despite claims of reform, 'crony socialism' has not been replaced with a more rational allocation of foreign exchange assets.

Third, how does marketization advance in the presence of a regime committed to monolithic rule? Spontaneous marketization has weakened the regime's surveillance capacities $^{71}$ and even sparked unorganized political dissent. ${ }^{72}$ Although the current regime has not attempted to reverse marketization, ambivalence persists. For


repudiated 'reform and openness', the slogan associated with China's 'mono transition' path:

Despite the filthy wind of 'reform and openness' blowing in our neighbourhood, we let the spirit of military-first rifles fly and advanced according to the path of socialism that we had chosen. ${ }^{73}$

\footnotetext{
${ }^{70}$ Y.-J. Park, 'One year after the execution of Jang Sung-Taek: the shifts of power and privilege in North Korea', KINU Online Series CO14-17, 2014, pp. 9-10,
} https://www.facebook.com/KINU1991eng/ [accessed 12 October 2014]

${ }^{71}$ A. Lankov and I.-O. Kwak, 'The decline of the North Korean surveillance state', North Korean Review, 7 (2) (2011), pp. 6-21.

${ }^{72}$ H.-M. Joo, 'Hidden transcripts in marketplaces: politicized discourses in the North Korean shadow economy', The Pacific Review, 27 (1) (2014), pp. 49-71

${ }^{73}$ R. Frank, 'The $7^{\text {th }}$ party congress in North Korea: an analysis of Kim Jong-Un's report', The Asia-Pacific Journal: Japan Focus, 14 (4) (2016b), p. 5, http://apjif.org/2016/14/Frank.html [accessed 22 May 2016] 
Monolithic rule is not conducive to the development of market supporting institutions, especially property rights based on the rule of law. ${ }^{74}$ The political environment remains inhospitable to entrepreneurship. For example, surveys of defectors found that party members did not engage in commerce directly but instead preferred to use their power to extract rents. Thus, the merchant class came predominantly from the middle and lower classes rather than those with the best class backgrounds or sŏngbun ('composition') (i.e. history of family service to the regime). ${ }^{75}$ This behavior would suggest that enterprise exists in spite of the regime and not because of it. For $\mathrm{Smith}^{76}$ and Choi, ${ }^{77}$ the violent purges of the Kim ChŏngŬn era are symptomatic not of monolithic rule but of divided elites fighting over market opportunities. In their view, this vicious high politics demonstrates that marketization is well entrenched. Need and greed have supplanted the hegemonic (i.e. consent-based) dimension that previously underpinned monolithic rule. However, this type of zero-sum environment of political contestation would not appear to be conducive to the development of market institutions either.

\footnotetext{
${ }^{74}$ Noland (2015), op. cit.

${ }^{75}$ B.-R. Kim, 'Marketization of North Korea and changes in the social class structure', IFES Focus on Korean Peninsula, $\quad 30 \quad$ (2015),
} http://ifes.kyungnam.ac.kr/eng/common/popup/PUB_Contents.aspx?code=PRI150313 0001 [accessed 8 December 2015]

${ }^{76}$ H. Smith, 'North Korea: intra-elite conflict and the relevance for global security', PacNet 41, 2017, $\quad$ https://www.csis.org/analysis/pacnet-41-north-korea-intra-elite-conflict-and-relevanceglobal-security [accessed 6 June 2017]

77 Y.-S. Choi, 'North Korea's hegemonic rule and its collapse', The Pacific Review, 30 (5) (2017), pp. $783-800$. 


\section{Framework for re-examining the sources of economic reform}

The three contentious issues above represent the most common doubts about the reform commitment of the North Korean regime despite the recent announcements of reform and positive economic signals. I will show how the sources of economic reform (structural factors and political calculus) identified above have enabled these constraints to marketization to be overcome. This can be represented as in Table 2 .

Table 2 about here

Table 2 illustrates the effects of both structural trends and political calculus. As for the regime's dependence on its core constituencies, the structural legacy of failed planning and economic collapse has forced the majority of core constituents to depend on the market to some degree. Another structural factor is the nature of the MLS itself. As a system that maximizes the authority of the Supreme Leader, it gives him great autonomy to redefine the economic ideology in market terms. In terms of political calculus, the political consolidation of the new regime depends on funds, for which the market and rebalanced expenditure ('parallel advance') represent the obvious sources. The rebalance is reflected in the tighter leash on the military, including curtailing of some of its foreign exchange privileges.

In relation to 'crony socialism', the monopolies and oligopolies dominated by core agencies can only function on the basis of cooperation with non-state agents (who possess the requisite funds and skills). This need brings about wealth sharing and wealth creation as well as bureaucratic profit-taking. Structural interdependence was reinforced by political calculus, which led the Kim Chŏng-Ŭn regime to 
introduce micro-economic measures (in agriculture and light industry) based on profit-motive and expanded opportunities for non-state agents. The purges related to foreign exchange assets represent efforts by the centre (Kim Chŏng-Ŭn) to strengthen its control over the finances of the core agencies while cooperative relationships with non-state agents remained intact.

As for the constraint posed by monolithic rule, mutual dependence and repeated interaction is leading to the emergence of a 'symbiosis' between core agencies and non-state agents. Policy reversal has become increasingly difficult. The regime's politically motivated drive to boost consumption further reinforces mutual dependence. For example, the regime seeks private support to deliver in politically prioritized areas such as housing. Finally, by improving the official finances, marketization enables the regime to pursue 'civilized country with socialism' as an alternative to regime modification experienced under the 'mono transition regimes'. We can now explore each of these issues in more detail.

\section{Marketization and the 'core constituencies'}

By the time Kim Chŏng-Ǔn assumed power in 2012, the 'core constituencies' had already been exposed to two decades of crisis-induced marketization. First permitted by the Kim Il-Sŏng regime in the 1980s, informal market activities gained momentum as the termination of Soviet and Chinese 'friendship prices' (1990-91) brought the official economy to the edge of collapse. When three consecutive years of bad weather (1995-7) tipped the country into famine (so-called 'arduous march'), the Kim Chŏng-Il regime drastically streamlined the central planning process. Apart from some 'special enterprises' (e.g. defence-related and heavy industries) and 
infrastructure (especially power generation), central government devolved economic responsibility down to local level administration, enterprises and farms to provide for their own production and consumption needs. While some sections of 'core constituencies' (especially workers of 'special enterprises') could rely on state provision to a greater degree, most economic units and individuals came to rely on informal market activities to some degree. ${ }^{78}$ The informal sector became the principal provider for people's livelihoods by 2000, a telling indicator of exposure to marketization. ${ }^{79}$

This background of structurally driven marketization was reinforced by the political motivations of the new Kim Chŏng-Ǔn regime. As mentioned above, Kim Chŏng-Ǔn could not rely on bloodline inheritance to the same extent as his father and had to build his own performance-based legitimacy. ${ }^{80}$ As a hereditary successor, he identified with his father's practical achievements, especially nuclear development and preservation of the North Korean state despite the collapse of the Soviet bloc. On the other hand, he was seeking to distance himself from economic hardship, the most unpopular feature of his father's 'military first' era. To distance himself from his father's unpopular legacies while establishing his own identity, he looked to economic development. While he did not think it wise to repudiate his father's security legacy, he also sought to rebalance the regime's priorities. His first public speech of 15 April 2012, when he pledged that austerity would never be

\footnotetext{
${ }^{78}$ M.-S. Yang (2015e), op. cit., pp. 26-7, 98-9.

79 The informal sector constituted 'almost 60 per cent of staple food grains and 70 per cent of necessities in the mid-1990s'. See Lim (2009), op. cit., p. 11.

${ }^{80}$ Frank and Park, op. cit., p. 43.
} 
KOREA

repeated (acknowledging the pain that austerity had brought), was an early indicator that consumption (People's Economy) would receive greater priority.

The pattern of policy announcements and appointments following the 15 April speech suggested the emergence of a reform pathway designed to enhance the core sectors' reliance on the market. On 28 June 2012, the authorities announced the introduction of 'New Economic Management System in Our Own Style'. These 628 Measures, as they became known, outlined policies for giving greater autonomy to the agricultural and light industrial sectors (core sectors of the People's Economy). The policies resembled the early stage of China's 'reform and openness', even though North Korea never embraced that slogan. In contrast to the aftermath of the 7-1 reforms of 2002, the 6-28 Measures were reinforced by the further measures of 30 May 2014. Under these 5-30 Measures, Kim Chŏng-Ǔn referred to the 'socialist corporate responsibility system, ${ }^{81}$ The switch towards economic reform was also apparent from the reappointment of Pak Pong-Ju to the position of Prime Minister (April 1st 2013). As one of the architects of the 2002-5 cycle of reform, Pak had served as premier during 2003-7. He was one of the 'Big Four' technocrats who led the 2002-5 reforms. At the Seventh Party Congress of May 2016, Pak was further

\footnotetext{
${ }^{81}$ M.-S. Yang, 'North Korea's marketization in the Kim Jong-Un era', IFES Focus on Korean $\begin{array}{lllllll}\text { Peninsula, } & 32 & \text { (2) } & \text { (2015d), } & \text { pp. 49-57, } & \text { at } & \text { p. }\end{array}$ http://ifes.kyungnam.ac.kr/eng/PUB/PUB 0501V.aspx?code=PRI150901_0001_[accessed 22
} November 2015] 
KOREA

promoted to the five-member Presidium (equivalent to China's Standing Committee) of the Politburo and also to the KWP's Central Military Committee. ${ }^{82}$

Any serious attempt to rebalance towards popular consumption meant shifting resources away from the military sector, both in terms of reduced central defence expenditure and reassignment of foreign exchange assets devolved to the military under Kim Chŏng-Il's 'military first' policy. Following on from his 15 April speech, Kim Chŏng-Ǔn gave further hints of this rebalance. For example, in a meeting with senior officials in mid-June 2012, Kim had reportedly said 'food grain is more important than bullets today'. ${ }^{83}$ Kim Chŏng-Ŭn's pattern of public activities between 2012 and 2015 revealed a shift towards a greater emphasis on economic rather than military goals. ${ }^{84}$ The rebalancing was officially acknowledged by the announcement of the doctrine of pyŏngjin nosŏn or 'line of parallel advance' (i.e. between nuclear-based defence and economy) in April 2013. 'Parallel advance' was a term first used by national founder Kim Il-Sŏng half a century earlier. This marked a modification of the Kim Chŏng-Il regime's emphasis on 'military first'. ${ }^{85}$ Of course, lip service continued to be paid to the achievements of 'military first'.

\footnotetext{
${ }^{82}$ Y.-J. Park, 'Assessment and prospect of the Seventh Congress of the Workers' Party of Korea: leadership system and elite group', KINU Online Series, CO16-13, 2016a, https://www.facebook.com/KINU1991eng/[accessed 22 May 2016]

${ }^{83}$ Cheong (2013), op. cit., p. 52.

${ }^{84}$ The balance (per cent) between economy and military was as follows: 24.5/32.5 (2012); 34.0/29.7 (2013); 36.0/32.5 (2014); and 44.9/30.2 (2015). See Y.-S. Jeon, 'The WPK's $70^{\text {th }}$ anniversary and strengthening of the party's political control', in 2016 DPRK Country Report, Korea Development Institute School of Public Management (ed.), KDI School, Seoul, 2015, pp. 18-54, at. p. 40.

${ }^{85}$ D.-Y. Kim, 2015), ' $70^{\text {th }}$ anniversary of the founding of the WPK and North Korea's military dilemma', in KDI School (ed.), op. cit., pp. 56-85.
} 
KOREA

Marking the announcement of 'parallel advance', the headline of the KWP newspaper, Rodong Sinmun (5 April 2013) quoted from Kim Chŏng-Ǔn's speech:

The most important and desperate task facing our party today is pressing the development of an economically powerful country and dramatically improving the lives of the people. ${ }^{86}$

In reality, Kim Il-Sŏng's 'parallel advance' initiated several decades of military build-up and austerity. The use of the slogan in the 2010s was designed to connote continuity and association with the optimistic early 1960 s but the content represented a shift away from military-bias. One year before the announcement of 'parallel advance' in April 2013 and the reappointment of Pak Pong-Ju as premier, some tentative changes were already occurring in this direction. The first sign of change came in April 2012 when the Cabinet, the part of the regime responsible for the People's Economy, was designated as the 'economic headquarters'. Kim ChŏngǓn reportedly said:

We must establish discipline and order in a way to concentrate all economic problems in the Cabinet and solve them under its command should we make a revolutionary turn in improving the standard of people's living and turning the country into an economic power. $^{87}$

\footnotetext{
${ }^{86}$ Ibid. p. 61

${ }^{87}$ Cheong (2013), op. cit., p. 53.
} 
Despite being a new leader, Kim Chŏng-Ǔn appeared to have the political authority as well as the political incentive to initiate 'marketization from above'. To begin with, he occupied the position of Supreme Leader within the MLS. While it has been criticized for inhibiting economic reform, the MLS also invested the Supreme Leader with a high degree of autonomy to redefine the official ideology as he saw fit. The only absolute principle was total allegiance to the Supreme Leader and his prevailing orders. This had enabled Kim Chŏng-Il to dismantle much of the elaborate central planning system created by his father and justify the move towards 'selfresponsibility'. Similarly, Kim Chŏng-Ǔn also had leeway to redefine what constituted 'socialism' and the sacred official principle of chuch'e ('national autonomy').

As a share of the government budget, military expenditure has been officially (under) stated as either 15.8 per cent $(2009-12,2016)$ or 15.9 per cent (2014 and 2015). ${ }^{88}$ However, it is possible to identify tentative shifts away from military bias in other ways. One significant development was the transfer of military rights for most foreign currency projects (except for arms exports) to the Cabinet. This was a response to the military's corruption and inflexibility as the leading economic institution. ${ }^{89}$ The military Chief-of-Staff, Vice Marshal Ri Yŏng-Ho, was dismissed in July 2012, ostensibly for opposing this transfer. Ri's dismissal was the culmination of a longer process of reallocating economic authority. In February 2012, a 'party life guidance group' was dispatched to military units with the aim of uncovering the abuse of authority, including activities related to foreign exchange. Foreign currency factions and clans underwent disciplinary measures with many

\footnotetext{
${ }^{88}$ Frank (2016a), op. cit.

${ }^{89}$ Cheong (2013), op. cit., p. 53
} 
KOREA

senior officers being replaced. The military's wartime rice reserves were released for state ration, thereby contributing to the stabilization of market prices in $2013 .{ }^{90} \mathrm{In}$ this respect, Kim Chŏng-Ŭn has been more successful than his father. ${ }^{91}$ The annual number of soldiers mobilized for economic tasks also doubled under Kim ChŏngŬn, to about $200,000 .{ }^{92}$

The transfer of foreign exchange rights and the dismissal of Vice Marshal Ri constituted a part of a wider process of reining in the military that had been empowered under Kim Chŏng-Il. Since 2012, the military has been subject to change by purge, reshuffle, new appointments and intensified KWP supervision. As the new Supreme Commander, Kim Chŏng-Ŭn promoted another 23 general-rank officers in February $2012 .{ }^{93}$ By the end of 2012, the regime had removed not only Vice Marshal Ri but also the other three top military officers who had accompanied the hearse at Kim Chŏng-Il's funeral in December 2011. ${ }^{94}$ The defense minister changed six times

\footnotetext{
${ }^{90}$ H.-J. Park (2013b), op. cit., p. 3.

91 The ill-fated currency redenomination of 2009-10 was ostensibly aimed at curbing the military's foreign currency activities but the military sabotaged the initiative by failing to release rice reserves to support the rationing system and stabilize prices. See H.-J. Park, 'Kim Jong Il, the military and the
} party, and Kim Jong Un', KINU Online Series CO10-12, 2010, https://www.facebook.com/KINU1991eng/ [accessed 4_January 2011]

${ }^{92}$ I am grateful to Dr Seong-Chang Cheong for this observation (Discussion, 14 April 2016).

${ }^{93}$ Preceding this, Kim Chŏng-Il promoted 185 military officers to the rank of general or gave them an extra star during 2010-11 to ensure the senior military's loyalty to his successor. See K.-D. Lee, S.-H. Lim, J.-H. Cho and J.-H. Song, Study on the Power Elite of the Kim Jong Un Regime, Korea Institute of National Unification, Study Series 13-01, Seoul, 2013, pp. 57-8.

${ }^{94}$ A. Mansourov, 'Kim Jong Un's first 100 days: consolidating power and clearing political space for national revival', International Journal of Korean Unification Studies, 22 (1) (2013), pp. 81-108, at p. 90 . 
KOREA

between 2013 and 2015. One (Hyŏn Yŏng-Ch’ŭl) was executed in April 2015 for 'militarism-based bureaucracy' or putting professionalism over politics and for showing irreverence towards Kim Chŏng-Ŭn. This showed that no measure of disobedience would be tolerated. The General Political Bureau that supervised the military for the KWP was strengthened and placed under the leadership of party professional Choe Ryŏng-Hae (now accorded the highest military rank of Vice Marshal). ${ }^{95}$

\section{'Crony socialism': wealth sharing and wealth creation}

'Crony socialism' began in 1974 when heir-apparent Kim Chŏng-Il began to reassign trading companies from the Ministry of Foreign Trade to Office 39, a newly created KWP financial unit. This enabled the Kims to divert foreign exchange from the official People's Economy into the hereditary succession project. ${ }^{96}$ The 'patrimonial' economy became more pronounced as the official economy deteriorated in the early 1990s. In 1991, the regime created the New Trading System that set foreign exchange targets for all core agencies. Different branches of the same agency established their own trading companies, a trend replicated at the local level. ${ }^{97}$ During the famine, these core agencies were given control of foreign

\footnotetext{
${ }^{95}$ S.-C. Cheong, 'Purge of Hyon Yong-Chol and outlook on party-army relations in North Korea', Vantage Point: Developments in North Korea, 38 (7) (2015), pp. 10-15, at pp. 12-15.

${ }^{96}$ H.-J. Park and S. Choi, Fiscal Segmentation and Economic Changes in North Korea, Korea Institute for National Unification, Study Series 14-05, Seoul, 2014, p. 14.

${ }^{97}$ Ibid. pp. 36-7
} 
KOREA

exchange assets in order to support themselves and to contribute to central funds. ${ }^{98}$ Kim Chŏng-Il himself would allocate the trading licences or $w a k k u^{99}$ required for participation in foreign exchange activities. Core agencies (usually operating through a trading company) would make a business proposal and seek Kim's approval. If approved, the proposals would become 'party directives' ${ }^{100}$ Prioritised under 'military first', the military came to dominate cash generators like raw materials, fisheries, mushrooms and ginseng. ${ }^{101}$

'Crony socialism' thus appears to concentrate wealth among the rapacious elites instead of creating new wealth. This would coincide with estimates of stagnant GDP. However, this perspective overlooks the extent of financial power accrued by nonstate agents as a result of 'marketization from below' since the 1990s. The entrepreneurship that sprang up in response to the failure of state planning also penetrated into the state sector. Kim and Yang identified two types of private entrepreneur. ${ }^{102}$ 'Necessity driven" entrepreneurs were motivated by difficult circumstances and confined their activities largely to private farming and handicrafts. The more ambitious 'opportunity driven' entrepreneurs were those whose activities reached into the state sector by way of investment and

\footnotetext{
${ }^{98}$ Ibid. p. 43

${ }^{99}$ Wak or Wakku (와꾸) is a form of North Korean slang (meaning 'trade license') not used in the South.

100 Yang (2015e), op. cit., pp. 29-30.

${ }^{101}$ J.-J. Suh, Economic Hardship and Regime Sustainability in North Korea, Korea Institute for National Unification, Studies Series 08-06, Seoul, 2008, pp. 21-2.

${ }^{102}$ S.-J. Kim and M.-S. Yang (2015), The Growth of the Informal Economy in North Korea, Korea Institute of National Unification, Studies Series 15-02, Seoul, p. 21.
} 
management. ${ }^{103}$ From this group sprang the private financiers or tonju (literally meaning 'owner of money') or the new rich who had amassed an average of one million US dollars, a huge sum by North Korean standards. ${ }^{104}$ They have become important economic partners of the state.

Mutually profitable relationships existed at many levels. At the most basic level, private entrepreneurs would obtain official permission to start businesses using state assets. For example, individuals would rent space from the state to open up a service business or to use as storage space. To do this, they would borrow titles from state agencies and enterprises for a fee. ${ }^{105}$ This 'name lending' or 'wearing the red hat' resembled the Chinese "registration" (guahao) system of the 1980s. A more ambitious form of cooperation was 'loan investment' whereby tonju would invest into SOEs in return for interest (profit). Because they lacked money, state entities (factories, stores, trading companies, and even banks) would turn to tonju for loans, investments and outsourcing of contract processing. ${ }^{106}$ For SOEs facing government production quotas (i.e. those key plants within the official economy) without receiving the necessary inputs, they had to turn to tonju for finance. ${ }^{107}$

Given its power, the military made the most attractive institutional patron for aspiring entrepreneurs. ${ }^{108}$ But even for that powerful core agency, the relationship ran both ways. To profit from its control of assets, it had to cooperate with civilians.

\footnotetext{
103 Ibid.

${ }^{104}$ Y.-J. Park (2016b), op. cit., p. 140.

105 Yang (2015e), op. cit., pp. 59-60.

${ }^{106}$ Ibid. p. 61.

${ }^{107}$ Kim and Yang, op. cit., pp. 19-20.

108 Y.-J. Park, (2016b), op. cit., pp. 143-4.
} 
KOREA

Despite having enormous manpower, it relied on support from sub-contract civilian labour. ${ }^{109}$ Sub-contract labour consisted of under-employed workers from the People's Economy who retained their formal work registration out of political requirement. Like other state agencies, the military needed investment and entrepreneurial skills. In this way, the core agencies and entrepreneurs (especially tonju) became interdependent. To maintain their authorization or wakku, the core agencies would be expected to contribute to the centre's 'revolutionary funds' ${ }^{110} \mathrm{By}$ extension, the Supreme Leader also came to depend on business cooperation with non-state agents. Despite reversion to anti-marketization from late 2005, the Kim Chŏng-Il regime continued to facilitate private investment into key export sectors. For example, the 'Regulations for the Development and Operation of Small and Medium Sized Mines' (2006) allowed any agency or business organization to develop and operate mines independently once they had received state authorization. ${ }^{111}$ Yang has usefully summarized the symbiotic relationships in the export sector as in Figure 1.

Figure 1 about here

The above discussion has established that in order to prosper, the core agencies need the cooperation of informal business partners and informal workers, with

\footnotetext{
${ }^{109}$ Suh, op. cit., pp. 21-2.

${ }^{110}$ Park and Choi, op. cit., pp. 45-6; M.-S. Yang, 'Measures for improving economic management under Kim Jong-Un's leadership and their assessment: 2012-14', Vantage Point: Developments in North Korea, 38 (6) (2015b), pp. 38-49, at p. 33.

${ }^{111}$ Kim and Yang, op. cit., p. 23.
} 
whom profits would be shared. The question remains as to whether 'crony socialism' allows for qualitative change (towards higher value-added production) or does it remain trapped in low productivity raw material exports? The profile of exports to China, the principal market for these 'point source' assets ${ }^{112}$ points to qualitative change rather than stagnation. While raw materials remained the dominant export, other exports are also significant. For example, manufacturing export based on textiles (a typical export of early stage developing economies) accounts for a significant share. As a share exports to China, textiles accounted for USD 108 million (21.6 per cent) (2005), USD 186.4 million (15.7 per cent) (2010), USD 587 million (20.1 per cent) (2013), and USD 799.3 million (32.2 per cent) (2015). ${ }^{113}$

The introduction of reforms aimed at resuscitating the productivity of the People's Economy also differentiates North Korea from typical crony political economies based on primary resource extraction. Facing competition from the informal markets, the cautious Kim Chŏng-Il regime had already started to do this with the 7-1 measures (2002). Two such policies were the 'earned income indicator' and 'socialist barter markets'. The 'earned income indicator' was introduced to evaluate enterprise performance on the basis of quality over quantity. It allowed for autonomous production and distribution. 'Socialist barter markets' enabled enterprises to exchange raw materials and parts. They permitted enterprises to exchange a certain ratio of products for materials. ${ }^{114}$ The fundamental problem of the 7-1 measures was that they introduced incentives (higher wages, higher prices,

\footnotetext{
112 As described by Noland, op. cit., 2015.

${ }^{113}$ NSO, op. cit. 'Textiles' consists of 'apparel and clothing accessories, knitted or crocheted' (code 61) and 'apparel and clothing accessories, not knitted or crocheted' (code 62).

${ }^{114}$ Yang (2015e), op. cit., pp. 54-5
} 
more enterprise and farm autonomy etc.) without first normalizing production (i.e. restoring productive capacity nearer to pre-crisis levels). Thus, they were more akin to efficiency measures for a sluggish planned economy than recovery measures for a broken one.

The Kim Chŏng-Ŭn regime has moved further in the direction of reforms aimed at improving the productivity of the People's Economy. Under the 6-28 (2012) and 5-30 (2014) measures, further incentives were introduced in agriculture and light industry, the sectors responsible for the people's consumption. Table 3 compares the 2002-5 and (on-going) 2012-15 reform periods.

Table 3 about here

The 2002 reforms showed that without first investing to normalize production, incentives could not take effect. The official sector continued to be unattractive to workers, as evidenced by their continued drift into the informal sector. In response to the need for 'pre-investment', the current government has been more flexible in its economic ideology. While retaining formal state ownership, the government has allowed for greater use of private funds. This has enabled private financiers to invest into state-run companies while receiving interest in return. ${ }^{115}$ Alternatively, individual entrepreneurs can lease state facilities and hire workers using their own funds. Provincial governments have also received permission to solicit investment

\footnotetext{
${ }^{115}$ E.-C. Lim, 'The formation and development of private financing in North Korea: patterns, implications and challenges', Vantage Point: Developments in North Korea, 38 (10) (2015a), pp. 3143 , at p. 35
} 
from private sources. ${ }^{116}$ These examples of private participation in state owned industry show how the state is licensing capitalist activity so long as it remains under nominal state ownership.

This section has argued that while 'crony socialism' undoubtedly exists, the most powerful cronies (the core power agencies) can only profit from their dominance of foreign exchange assets through input (of money and talent) from non-state agents. This results in profit sharing between core agencies and non-state agents. This pattern of cooperation persists irrespective of changes in ownership brought about by elite conflict. The growth of trade (with growing volume and composition of manufactures) and the spread of consumerism would suggest that new wealth is being created under 'crony socialism', and that it is confined not only to the elites. In respect of wealth creation, the measures taken by Kim Chŏng-Ǔn regime to boost the productivity (6-28 and 5-30 measures) of the People's Economy have expanded the opportunity for non-state agents to an unprecedented degree. The emphases on rebuilding People's Economy, bolstering the authority of the Cabinet, and reconstruction of infrastructure (especially power generation) indicates that Kim Chŏng-Ŭn is able to set clear priorities for the investment of state resources. As such, his authority appears to be getting stronger rather than being eroded by infighting among elite factions.

\section{Sustainability of marketization under monolithic rule}

\footnotetext{
${ }^{116}$ S.-K. Lee, 'The economic policy for the Kim Jong-Un regime in North Korea and the possibility of its change', Vantage Point: Developments in North Korea, 37 (1) (2014), pp. 46-57, at pp. 54-5.
} 
How sustainable is marketization in the presence of monolithic rule? I will argue that increasing cooperation between state agencies and informal capitalists has created links of interdependence that have become very costly for the regime to rupture. Moreover, the regime has no political necessity to rupture these links because it faces no prospective threat from its entrepreneurial allies. The failure of market-reversal during 2005-9 showed how the regime was already tightly locked into market cooperation with non-state agents. Market reversal policy brought about the very social instability that the regime feared. The capacity of major merchants and financiers to withstand anti-market measures, including currency reform, showed how deeply entrenched marketization had become. ${ }^{117}$ The ill-fated antimarket policies of 2005-9 arose because the Kim Chŏng-Il regime had reluctantly introduced reforms without modifying its economic ideology. By contrast, the current regime has officially committed itself to boosting popular consumption and Kim Chŏng-Ŭn has personally endorsed the profit motive. Whereas Kim Chŏng-Il (26 August 2007) denounced the market as, 'the habitat of anti-socialism,118 Kim Chŏng-Ŭn, referring to agricultural reform reportedly stated that:

\footnotetext{
${ }^{117}$ By the end of the Kim Chŏng-Il era, the 'merchant class' (i.e. those who traded as an occupation) was estimated to number between 500,000 and one million individuals (out of a population of 25 million), a significant pointer to the existence of grassroots capitalism. See Y.-S. Dong, 'The rise of North Korea's merchant class', SERI Quarterly, October 2013, pp. 67-72, at pp. 67-8. http://www.seriworld.org/16/qt_Section_list.html?mncd=0301\&dep=1 [accessed 10_November 2013]

${ }^{118}$ H.-J. Park (2010), op. cit., p. 3.
} 
egalitarianism in the realm of distribution has no connection to socialist principles and has a detrimental impact that reduces farmers' productivity ${ }^{119}$

The regime's growing acceptance of marketization is manifested in the official tolerance of informal property rights under the veneer of state ownership. Although formal 'property rights' still do not exist, private property has developed into a 'social custom' ${ }^{\prime 20}$ i.e. something that is widely accepted in practice. According to refugees, the three main items of 'property rights' are small land plots, market stands and housing. ${ }^{121}$ The first two items of individual private property also emerged in the early stages of reform socialism in China and Vietnam (i.e. low value assets that could easily be reconciled with state socialism). The penetration of property rights into the real estate (housing) sector, however, represents a significant advance. It represents the regime's de facto acceptance of private ownership, usage and transfer of a high value asset so long as the appropriate taxes are paid (see below). In the past, the government would have allocated such a valuable asset according to sŏngbun or one's (political) make-up. Now it is primarily concerned with obtaining revenue.

The range of 'concealed property rights' or private property under state guise is expanding. Private ownership of the means of production is permitted if it is incorporated into a state organization. ${ }^{122}$ Many forms of de facto private ownership

\footnotetext{
${ }^{119}$ Vantage Point, 'North Korea's attempts for agricultural reform', Vantage Point: Developments in North Korea, 37 (4) (2014), pp. 26-9, at p. 27.

${ }^{120}$ S.-J. Kim (2015a), op. cit., pp. 6-7

${ }^{121}$ Ministry of Unification, op. cit., p. 220.

${ }^{122}$ M.-S. Yang (2015a), op. cit.
} 
of productive facilities now exist. First, individuals can engage in cottage industries (family-sized manufacturing activities), private cultivation and private commerce. Second, individuals can manage a business using a state-run enterprise name ('wearing the red hat'), using leased state facilities while hiring workers with their own money (in effect, a labour market). Third, recently it was confirmed that in 2014 the government revised the law to permit rich individuals or tonju to invest in businesses. According to the Article 38 of the new law:

Following the established procedures, the enterprises can get a loan from the bank or mobilize and use the idle currency and funds in the hands of the people [my italics] to overcome the lack of working capital.

This is the first confirmation that the authorities have provided a legal basis for the use of informal savings. ${ }^{123}$ The attitude of the authorities appears to be pragmatic, namely, maintaining the appearance of state ownership while relaxing the substance for the sake of reviving production and collecting tax revenue. In effect, the informal capitalists can treat state-owned assets as if they are private assets. At the very least, their 'property rights' are secure enough for them to sink money and effort into state enterprises.

Apart from tolerating capitalist activity, the regime is actively soliciting non-state participation in the key projects designed to showcase official concern for popular

\footnotetext{
${ }^{123}$ IFES (Institute for Far Eastern Studies), 'North Korea revises business law to legalize private $\begin{array}{lllll}\text { investments', } & N K & \text { Brief } & \text { 06-2, }\end{array}$ http://ifes.kyungnam.ac.kr/eng/frm/FRM_0101V.aspx?code=FRM170613_0001_[accessed 29 July 2017]
} 
welfare. The non-state sector is playing a key role in the apartment construction boom in P'yŏngyang and other cities. A 'construction alliance' consisting of central government, core government agencies, financiers, and construction service providers has emerged in the process. As with trade, most apartment construction begins with core agencies seeking official licenses. Having obtained licenses, they then contract out to builders (often through brokers) capable of mobilizing funds, materials and manpower. It is estimated that private contractors are responsible for 80 per cent of apartment construction in North Korea and that one-third of new apartments are traded on the market (i.e. those not directly allocated by the government). ${ }^{124}$ Trading of apartments has become a very lucrative business. The asking price of new apartments reportedly ranges from USD 100,000 for a downtown $100 \mathrm{~m}^{2}$ apartment to USD 200,000 for the most expensive apartment located in the upmarket Pot'onggang district. ${ }^{125}$ Given the original purchase price was probably USD 30-40,000, this meant very high profit margins for those with cash to invest in purchase and re-modelling for resale. Since the apartments are included in the state construction plan, the private sector is playing a central role in fulfilling the regime's ambitious apartment construction programme associated with the rise of Kim Chŏng-Ŭn. ${ }^{126}$ The market for apartments shows that the non-state

\footnotetext{
${ }^{124}$ M. Hong, 'The apartment construction market and urban politics in North Korea', Vantage Point: Developments in North Korea, 37 (10) (2014), pp. 33-42, at p. 38.

${ }^{125}$ S.-H. Chu and C.-A. Kim, 'Three times the rate if you want South Korean hair-style ... Samsung TV in Pyongyang apartment: North Korea five years after the emergence of Kim Jong-Un', donga.news, 17 September 2015, http://news.donga.com/View?gid=73674583\&date=20150917 [accessed 20 September 2015]

${ }^{126}$ Hong, op. cit., p. 38
} 
KOREA

agents feel secure enough to risk sizeable amounts of capital in a long-term venture like construction.

Apart from the real estate market, the state is actively facilitating popular consumption (especially in P'yŏngyang) in order to build political support and collect tax. Towards these objectives, it has facilitated non-state agents and become a provider in its own right. The reorganization of 'farmers' markets' into 'general markets' (2003) expanded the range of products for open sale and created an important source of official revenue. ${ }^{127}$ During the 2010s, this system has developed further. Department stores, general markets, restaurants, and entertainment facilities have proliferated in P'yŏngyang and the surrounding areas. ${ }^{128}$ By 2015, 26 public markets existed in P'yŏngyang, covering all districts, compared to just one in the early 1990s. ${ }^{129}$ Frequent visitors have noticed the development of a thriving Chinese-style facility at the state-owned Kwangbok Area Shopping Centre. ${ }^{130}$ Since 2012, three types of state electronic payment cards have been introduced for cashfree payment at foreign exchange shops. Easily acquired, these cards speed up

127 Y.-S. Chang and E.-M. Jeong, Double-Sidedness of North Korea, Institute of Unification Education, Seoul, 2015, pp. 78-9.

${ }^{128}$ Ibid. p. 90.

${ }^{129}$ E.-L. Joung, 'North Korea's economic policy as a duet with control and relaxation: dynamics arising from the development of public markets since the North Korean famines in the 1990s', Journal of Asian Public Policy, 9 (1) (2016), pp. 75-94, at p. 92.

${ }^{130}$ For example, see R. Frank, 'Witnessing change in North Korea: a view from the ground', Global Asia, 12 (2) (2017b), pp. 104-15. 
purchases and help increase the total volume of financial transactions. ${ }^{131}$ Outside of P'yŏngyang, the 'state dollar collection system' also exists. One manifestation is the rental fee levied by the state on vendors at market squares. ${ }^{132}$

What do these developments tell us? First, the authorities have become increasingly confident of living with marketization and consumerism (including the development of a mobile telephone network), even if it continues to suppress some manifestations (such as South Korean DVDs). Second, by providing consumer products and services previously neglected by the state, the informal sector has also opened up tax opportunities for the state (via the 'state-dollar collection system'). These activities are simultaneously meeting popular demand and contributing to the finances of the state. South Korean estimates of the North Korean government budget (which tend to under-estimate) suggest continuous recovery (2009-15) despite international sanctions. The estimates are (billion USD): 3.7 (2009); 5.2 (2010); 5.8 (2011); 6.2 (2012); 6.8 (2013); 7.1 (2014); and 6.9 (2015). ${ }^{133}$ Third, under the influence of the informal sector (and China), state agents themselves are becoming 'entrepreneurial', capable of profitably supplying products and services of increasing sophistication, including credit cards. The improvements concentrated in P'yŏngyang appear to be spreading out to the rest of the country. It would seem

131 IFES, 'Expanding electronic payment system in North Korea', NK Brief 06-4, 2017b, http://ifes.kyungnam.ac.kr/eng/FRM/FRM 0101V.aspx?code=FRM170627_0001 [accessed 15 July 2017]

${ }^{132}$ K.-S. Lee, 'Current trends and characteristics of the North Korean economy and its future outlook at the $70^{\text {th }}$ anniversary of the founding of the WPK', in KDI School (ed.), op. cit., 2015, pp. 117-44, at p. 133.

${ }^{133}$ NSO, op. cit. 
the regime is tackling the incentive problem at the heart of state socialism's economic malaise.

The Kim Chŏng-Ǔn regime appears to enjoy a cosy and productive relationship with the nascent capitalists (merchants, entrepreneurs and financiers). Far from posing a political challenge, these nascent capitalists depend on political patronage. ${ }^{134}$ Given that the assets from which they extract profit remain under state ownership, continuing access depends on maintaining smooth collaboration with the core agencies. In particular, the most profitable activities (e.g. export of raw materials, real estate and construction) depend on collaboration with those core agencies (especially party, military, security) that have most licensing authority. Without the regime, these nascent capitalists would lose their market space to foreign capitalists. Not only are they locked into interdependence with the regime, they are too divided (by social background, business size and source of bureaucratic support) to form the basis of any 'civil society' capable of confronting the state. ${ }^{135}$ For its part, the regime seems to recognize the nascent capitalists to be safe economic partners. The purges arising from elite conflicts over foreign exchange distribution affect the leaders of the core agencies rather than their informal capitalist partners. The latter's access to state protection usually remains unchanged.

Historically the transition towards 'mature post-totalitarianism' (characterized by increased consumerism, limited political liberalization, and the modification of political institutions) was accompanied by de-legitimization of traditional communist values. Regimes instead governed on the basis of 'pragmatic

\footnotetext{
${ }^{134}$ Smith (2015), op. cit., pp. 289-90.

135 Y.-J. Park (2016b), op. cit., p 151.
} 
acceptance' ${ }^{136}$ or 'social contract'. China and Vietnam have shown how marketization can provide resources for ruling regimes to renew themselves materially (greater capacity for party supervision) and ideologically (promotion of new social values consistent with one-party rule such as nationalism). ${ }^{137}$ In this way, they have avoided the fatal ideological de-legitimization suffered by the Soviet bloc regimes. The North Korean regime has been even more determined than its Asian counterparts to pre-empt the problems of de-legitimization associated with marketization. Economically, its position resembles the early 'post-totalitarian' stage in which the regime has decisively endorsed marketization. In the political sense, however, North Korea remains very much 'totalitarian'. Marketization, however, has not been accompanied by a political thaw or by the dilution of monolithic rule based on the Supreme Leader. By contrast, intensification of the Kim Chŏng-Ŭn personality cult, the frequency of terror-based purges, and revived leadership role of the KWP since 2010 (as the military's political role has been de-emphasized) serve to demarcate the rigid political sphere from the liberalizing economic one.

This demarcation is also happening in a more sophisticated way. Far from 'posttotalitarian' modification of the regime in response to marketization, marketization is utilized to reinforce the monolithic regime's legitimacy (led by the revived KWP). While Kim Chŏng-Ǔn's economy-focus appears to be very much attuned to the

\footnotetext{
${ }^{136}$ Saxonberg, op. cit., pp. 288-9.

${ }^{137}$ Recent research has found that popular support for the Chinese regime extends beyond instrumental economic commitment. For example, see B.J. Dickson, The Dictator's Dilemma: The Chinese Communist Party's Strategy for Survival, Oxford University Press, New York, 2016.
} 
material aspirations of those in their 30 s (i.e. his generation), ${ }^{138}$ his rule is not simply based on 'social contract'. There is renewed emphasis on ideology. For example, Kim Chŏng-Ŭn has emphasised the achievement of 'civilized country with socialism' since 2013. Aimed particularly at youth, 'civilized country with socialism' seeks to bind the 'market generation' to the regime. ${ }^{139}$ It means boosting social satisfaction by investment of the fruits of economic development into collective benefits (e.g. extension of compulsory education, provision of recreational, housing and retail facilities, improvement of medical provision, development of sporting prowess). Naturally, these collective benefits of growth have been accompanied by parallel ideological efforts to extol the achievements of the ruling Kim dynasty. ${ }^{140}$ In this way, individual consumerism would be balanced by government efforts to nurture pride in the state and loyalty towards the Supreme Leader. Moreover, the nature of the MLS is such that the Supreme Leader has great flexibility in interpreting policy. As such, the regime is less bound by commitment to specific economic principles

${ }^{138}$ This is the view of former Minister of Unification Lee Jong-Seok. See B.-Y. Hwang and H.K. An, 'Kim Jong-Un's objective is Chinese-style rapid growth ... his father's testament: former Minister of Unification looks at Kim Jong-Un's dream', Ohmynews 5 April 2018, http://m.ohmynews.com/NWS_Web/Mobile/at_pg.aspx?CNTN_CD=A0002421483\&CMPT_CD=

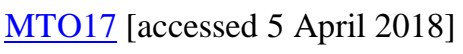

${ }^{139}$ KINU North Korea Studies Division, ‘Analysis of North Korea’s 2016 New Year’s address and domestic and foreign policy outlook', KINU Online Series, CO16-01, 2016, pp. 5-7, https://www.facebook.com/KINU1991eng/?hc_ref=ARSrDnkqBqXaIiD7akVCKdZOMLxs2sJaIzGYxzOULh5r761XxLRD9KF0va23jL367s\&fref=nf [accessed 6 March 2016]

${ }^{140}$ E.-C. Lim, 'The goal and the current status of building a "civilized country with socialism" at the $70^{\text {th }}$ anniversary of the foundation of the party', in KDI School (ed.), op. cit., 2015b, pp. 145-75. 
(such as egalitarianism or central planning). So far, there appears to be no contradiction between marketization and the absence of liberalizing political change. Even those commentators who have doubted the regime's capacity for reform concede that the regime may have hit upon a viable formula for preserving power. ${ }^{141}$

\section{Conclusion}

Improved economic indicators and economic policy trends during the 2010s lend support to the alternative perspective that North Korea is becoming more economically flexible despite its adherence to monolithic rule. This perspective identifies structural forces (the momentum of twenty years of spontaneous marketization) and political calculus (especially regime consolidation following the second hereditary succession) as the driving forces of economic flexibility. This article delved further into three contentious issues often raised in critical response to the alternative perspective. First, it found a subtle but distinctive change in the regime's leitmotif in the direction of economic development (from 'military first' to 'parallel advance'). An indication of this change was the attempt to curb the privileges and power of the military, the ultimate 'core constituency'. Second, it found that the economic dangers of 'crony socialism' are balanced by the core agencies' interdependence with non-state agents (especially financiers) who are also enjoying more market opportunities owing to official emphasis on boosting popular consumption. Third, regarding the compatibility of marketization with renewed

${ }^{141}$ For example, S. Haggard, 'Kim Jong Un: a new ruling formula?', North Korea: Witness to Transformation, 2015, https://piie.com/blogs/north-korea-witness-transformation/kim-jong-un-new-

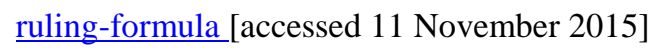


monolithic rule, the current regime appears more habituated to marketization than its predecessor (e.g. Kim Chŏng-Ǔn's positive evaluation of profit, extension of informal property rights, non-state agents' participation in key state projects and state entrepreneurship in the consumer sectors). In contrast to modification of political institutions under 'mono transition', the North Korean regime appears confident that it can reconcile individual prosperity with monolithic politics ('civilized country with socialism').

The favourable marketization trends identified above are subject to external conditions not deteriorating further. 'Parallel advance' (simultaneous promotion of nuclear defence and economic development) has enabled the regime to rebalance its priorities between military and economy but ensures that North Korea continues to face international isolation, setting it apart from the other 'mono transition' regimes. While North Korea's leaders can take some comfort from the continuation of economic growth amid international sanctions, the tightening of sanctions has inevitably undermined the economy's growth potential. It appears that the North Korean leadership has come to appreciate this dilemma. In the spring of 2018, it initiated peaceful overtures that led to three summits each with China and South Korea and one with the US (as of October 2018), all of which resulted in hopeful statements of agreement. Underpinning this diplomacy was Kim Chŏng-Ǔn's announcement of the road of 'economy-first' in place of 'parallel advance' (March 2018). Having seen authoritarian regimes deposed around the world, however, North Korea will consent to denuclearization only on the basis of ironclad security and economic guarantees.

The reduction of tension and continued advance of marketization will be greatly facilitated by the hopeful diplomatic developments of 2018, the most important 
aspect of which is the readiness of the US to engage with North Korea. Only this can ease the security obsession driving North Korea's WMD development. In practice, this should mean the improvement of diplomatic and economic relations between the US and North Korea in exchange for a moratorium on WMD testing followed by verifiable denuclearization measures. While it is the most important aspect of engagement, it is also the aspect most vulnerable to derailment, especially on the US side. This arises out of the ability and willingness of the current Trump administration to stay the diplomatic course in view of the manifold disputes (e.g. with China over trade, with its domestic opponents over everything) in which it is embroiled. Moreover, President Trump's lack of liberal-democratic idealism, which has so far facilitated direct engagement with North Korea, is well out of sync with the foreign policy sentiments prevalent in both major US political parties. Here, the continuing diplomatic efforts of China and South Korea work in the positive direction of bringing P'yŏngyang and Washington together. ${ }^{142}$ The hopeful trends of marketization identified in this paper will only be sustained if they are aligned with a peaceful external environment.

\section{Acknowledgements}

Research and writing of this article were kindly supported by the Academy of Korean Studies Grant AKS-2015-R21. I benefited greatly from my discussions

\footnotetext{
${ }^{142}$ On the objectives of the regional stakeholders, see J. Hemmings, R. Pacheco Pardo and T.Y. Kong, Negotiating the Peace: Diplomacy on the Korean Peninsula, Henry Jackson Society, London, 2018, https://www.researchgate.net/publication/327670448 Negotiating the Peace Diplomacy on the
} Korean_Peninsula [accessed 12 September 2018] 
KOREA

with many specialists especially Seong-Chang Cheong, Nam-Hoon Cho, Ruediger Frank, Dong-Ho Jo, Hyung-Min Joo, Byeong-Yeon Kim, Dong-Yub Kim, Suk Lee, Chung-In Moon, Hyeong-Jung Park and Hazel Smith. Hyo-Won Yoon and Eunmee Kim have always been welcoming and supportive during my frequent research trips to Korea. I would also like to thank the two anonymous reviewers for their helpful comments and the editorial team of Modern Asian Studies for their support. This article is dedicated to the memory of my sister Maisie (汇詠頣) (1965-2018). 